\title{
Identification and characterization of $R F R P$ gene in pigs and its association with reproductive traits
}

\author{
M.X. Fang', Y.S. Huang ${ }^{2,3}$, J. Ye ${ }^{2,3}$, W. Zhang ${ }^{2,3}$, Y. Li $^{4}$ and Q.H. Nie ${ }^{2,3}$ \\ ${ }^{1}$ Department of Laboratory Animal Science, \\ Medical College of Jinan University, Guangzhou, Guangdong, China \\ ${ }^{2}$ Department of Animal Genetics, Breeding and Reproduction, \\ College of Animal Science, South China Agricultural University, Guangzhou, \\ Guangdong, China \\ ${ }^{3}$ Guangdong Provincial Key Lab of Agro-Animal Genomics and Molecular \\ Breeding, Guangzhou, Guangdong, China \\ ${ }^{4}$ State Key Laboratory of Livestock and Poultry Breeding, \\ Institute of Animal Science, Guangdong Academy of Agricultural Science, \\ Guangzhou, Guangdong, China \\ Corresponding author: Q.H. Nie \\ E-mail: nqinghua@scau.edu.cn
}

Genet. Mol. Res. 13 (1): 1661-1671 (2014)

Received June 28, 2013

Accepted October 20, 2013

Published January 14, 2014

DOI http://dx.doi.org/10.4238/2014.January.14.8

\begin{abstract}
RFamide-related peptide $(R F R P)$ gene is a crucial gene of the hypothalamo-pituitary-gonadal axis and plays an important role in reproduction regulation. This study aimed to clone and characterize the pig RFRP gene. We obtained a 645-bp cDNA of pig RFRP gene comprising a 546-bp open reading frame, which encoded a peptide of 188 amino acids. The pig RFRP coding sequences have the identities of $81,68.8$, and $76.1 \%$ with their counterparts in humans, mice, and rats, respectively. Real-time polymerase chain reaction showed that the pig RFRP gene was expressed predominantly in the stomach and testis of males, and large intestine and uterus of females. It was also found
\end{abstract}


to be abundantly expressed in the cerebrum and liver tissues of both male and female pigs. The pig RFRP gene is $4.6 \mathrm{~kb}$ long and contains 3 exons and 2 introns. We further identified a total of 25 single nucleotide polymorphisms and 2 insertion/deletion (indel) polymorphisms across the whole RFRP gene, and 9 of them were in the exons. Marker trait association analysis in Yorkshire and Landrace populations showed that g. $45859759 \mathrm{C}>\mathrm{T}$ was significantly associated with the total number born of second parity (TBA2; $\mathrm{P}<0.05$ ). In conclusion, the pig $R F R P$ gene was cloned and characterized in this study, and its polymorphism g.45859759C $>$ T showed significant associations with reproductive traits.

Key words: Pig; $R F R P$ gene; SNP; Reproductive trait; Association analysis

\section{INTRODUCTION}

After its isolation from Macroeallista nimboia in 1977, FMRFamide was found to stimulate the heart and inhibit food intake (Price and Greenberg, 1977). Subsequently, a variety of peptides with an RFamide structure at their $\mathrm{C}$ terminus have been identified. Thus far, 5 types of peptides, including KISS, LPXRFa, QFRP, PQRFa, and PrRP, with the same RFamide structure have been identified from birds and mammals (Kriegsfeld, 2006; Ebling and Luckman, 2008). The RFamide-related peptide (RFRP) gene, a member of the RFamide family and an ortholog to the gonadotropin-inhibiting hormone $(\mathrm{GnIH})$ gene, was first detected in quail and found to encode 3 biological peptides, RFRP-1, RFRP-2, and RFRP-3 (Hinuma et al., 2000; Legagneux et al., 2009). In mammals, however, the RFRP gene only encodes 2 isoforms, RFRP-1 and RFRP-3.

The human RFRP gene at chromosome 7p21-p15 consists of 3 exons and 2 introns and encodes 2 major peptides, RFRP-1 and RFRP-3 (Hinuma et al., 2000). The function of RFRP gene is well studied in the nervous system, but limited in other peripheral systems. Hypothalamo-pituitary-gonadal is considered as a crucial axis that regulates reproductive activity through the secreted hormones (Kriegsfeld et al., 2010). Unlike the other 5 types of peptides, KISSpeptin has a more remarkable impact on puberty (Seminara et al., 2003). Until recently, RFRP was found to promote gonadotropin secretion via gonadotrophin releasing hormone $(\mathrm{GnRH})$ neurons (Yoshida et al., 2003; Ubuka et al., 2009). Accordingly, RFRP peptide might play a key role in the seasonal activity of reproduction dependent on melatonin. The level of RFRP mRNA was found to be reduced to a greater extent to facilitate adaption to the short-day photoperiod (SD) than to long-day photoperiod (LD; Revel et al., 2008). The RFRP peptide was indicated to have an important impact on food intake (Bechtold and Luckman, 2007; Clarke et al., 2009). Furthermore, RFRP-1 peptide might help the function of cardiac contractility and might be a target for future drug development (Nichols et al., 2010). Recently, RFRP-3 was found to inhibit the release and synthesis of $\mathrm{GnRH}$, gonadotrophin, and steroid hormones and impact the expression of KISS1, GnRHR, cyclin B1, PCNA, and ERK 1/2 (Li et al., 2013).

Therefore, the RFRP gene was thought to be a candidate gene for reproductive traits and energy balance. In pigs, the $R F R P$ gene has not yet been identified; therefore, we aimed to clone its cDNA to investigate its expression among various tissues and between males and females, as well as to reveal the associations of $R F R P$ gene polymorphisms with reproductive traits. 


\section{MATERIAL AND METHODS}

\section{Animals}

Two 120-day-old Yorkshire pigs (one female and one male) were slaughtered to collect 40 tissues (female, 21 and male, 19), i.e., cerebrum, cerebellum, hypothalamus, pituitary, heart, liver, spleen, lung, kidney, subcutaneous fat, abdominal fat, foreleg muscle, back leg muscle, back muscle, small intestine, large intestine, stomach, ovary, oviduct, uterus, and testicle. Only ovary and uterus were used to clone the pig $R F R P$ gene, and all tissues were used for real-time quantitative polymerase chain reaction (qPCR) analyses. Five females each of Yorkshire, Landrace, Duroc, Lantang, and Small-ear spotted pigs were used for the identification of polymorphisms across the complete coding region of the pig RFRP gene. Meanwhile, Yorkshire (sample size $=334)$ and Landrace $(187)$ populations were also used for marker trait association analyses. The detail record of total number born (TNB) and number born alive (NBA) from first to sixth parity of each female of these 2 populations was available. Small pieces of ears of all pigs were collected for the extraction of genomic DNA. These samples were provided by Guangdong Wens Foodstuff Corporation Ltd. (Guangdong, China) and Yunnan Province, China.

\section{Primers}

A total of 15 primers were used in this study (Table 1). Primers P1 and P2 for cDNA cloning were designed on the basis of the predicted RFRP cDNA sequences. P3 and P4 for pig $R F R P$ and $\beta$-actin genes each were used for qPCR analyses. P5-P10 were used for the identification of RFRP gene polymorphisms according to the pig genome database. P8 and P11P14 were designed to genotype 5 single nucleotide polymorphisms (SNPs) by the PCR-RFLP method. All primers were designed using the GeneTool Lite software (http://www.BioTools. $\mathrm{com} /$ ) and then synthesized by GeneRay Co. Ltd. (Shanghai, China).

\section{DNA extraction and RNA isolation}

Total RNA of Yorkshire (21 females and 1 male) pigs was extracted from fresh or frozen tissues by using Trizol reagent (Invitrogen, Carlsbad, CA, USA). cDNA was synthesized using $2 \mu \mathrm{g}$ total RNA by reverse transcription using PrimeScript RT reagent Kit (TaKaRa, China). Genomic DNA was extracted from pig ears by using the typical phenol-chloroform method (Sambrook et al., 1989).

\section{Cloning of pig RFRP cDNA}

RT-PCR was performed to amplify the RFRP cDNA from the ovary and uterus by using primers $\mathrm{P} 1$ and $\mathrm{P} 2$. The $50-\mu \mathrm{L}$ reaction mixtures contained $2 \mu \mathrm{L}$ cDNA, $1 \mu \mathrm{L}$ primers, $5 \mu \mathrm{L} 10 \mathrm{X}$ TransTaq HiFi buffer, $4 \mu \mathrm{L} 2.5 \mathrm{mM}$ dNTPs, $0.5 \mu \mathrm{L}$ TransTaq HiFi DNA polymerase, and distilled water. PCR was performed in a Mastercycler gradient (Eppendorf Limited, Hamburg, Germany) by using the following procedure: $94^{\circ} \mathrm{C}$ predenaturation for $3 \mathrm{~min}$, followed by 35 cycles of 30 s at $94^{\circ} \mathrm{C}, 30 \mathrm{~s}$ at $64^{\circ} \mathrm{C}$, and $45 \mathrm{~s}$ at $72^{\circ} \mathrm{C}$, and a final extension of $8 \mathrm{~min}$ at $72^{\circ} \mathrm{C}$. PCR products were checked on $1.5 \%$ agarose gels, and then purified using the Gel Extraction Kit (U-gene, Chi- 
na). Subsequently, PCR products were cloned into the pMD18-T Easy plasmid vector (Promega, USA), and then sequenced by BGI-Shenzhen (Guangdong, China) with commercial service.

\begin{tabular}{|c|c|c|c|c|c|}
\hline Gene & Primer & Sequence $\left(5^{\prime}-3^{\prime}\right)$ & AT $\left({ }^{\circ} \mathrm{C}\right)$ & Product size (bp) & Purpose \\
\hline \multirow[t]{3}{*}{ RFRP } & PM1 & $\begin{array}{l}\text { F: 5'-gctgcacacagaaactt-3' } \\
\text { R: 5'acttctgcatcatctatttcttg-3' }\end{array}$ & 64 & 601 & cDNA cloning by RT-PCR \\
\hline & PM2 & $\begin{array}{l}\text { F: 5'-atgggaaaaacaaaggagtctca-3' } \\
\text { R: 5'-aggctctggagttcttattttc-3' }\end{array}$ & 64 & 546 & \\
\hline & PM3 & $\begin{array}{l}\text { F: 5'-tcccaatctgccccaaag-3' } \\
\text { R: 5'-cccttggcagatggtgaa-3' }\end{array}$ & 60 & 103 & Real-time PCR \\
\hline$\beta$-actin & PM4 & $\begin{array}{l}\text { F: 5'-ccgtgagaagatgacccagat-3' } \\
\text { R: } 5^{\prime} \text {-gccagccaggtccagacgc-3' }\end{array}$ & 60 & 202 & \\
\hline \multirow[t]{10}{*}{ RFRP } & PM5 & $\begin{array}{l}\text { F: 5'-acggggatggatctcactgc-3' } \\
\text { R: } 5^{\prime} \text {-tgggcctagtctggggttaata-3' }\end{array}$ & 64 & 785 & Polymorphism in exon 1 \\
\hline & PM6 & $\begin{array}{l}\text { F: } 5^{\prime} \text {-gcccatcccacttcctc-3' } \\
\text { R: } 5^{\prime} \text {-tcccactgtettccatgtc-3' }\end{array}$ & 62 & 694 & PolymorphiSm in intron 1 \\
\hline & PM7 & $\begin{array}{l}\text { F: 5'-tggaaagacagtgggagacatc-3' } \\
\text { R: 5'-gcgggtgatggagtaaagtaac-3' }\end{array}$ & 62 & 764 & Polymorphism in exon 2 and PCR-RFLP \\
\hline & PM8 & $\begin{array}{l}\text { F: 5'-cctccacacttgcaccactga-3' } \\
\text { R: } 5^{\prime} \text {-ctgcggcaatgctggatc-3' }\end{array}$ & 63 & 878 & Polymorphism in intron 2 \\
\hline & PM9 & $\begin{array}{l}\text { F: 5'-atggctcctagtcagatttgttt-3' } \\
\text { R: } 5^{\prime} \text {-acctcagcagaacgtcagtg-3' }\end{array}$ & 55 & 864 & Polymorphism in intron 2 \\
\hline & PM10 & $\begin{array}{l}\text { F: 5'-aagcaaggggagccaaga-3' } \\
\text { R: 5'-gctgtactgagaaggaaaaattg-3' }\end{array}$ & 60 & 643 & Polymorphism in exon 3 \\
\hline & PM11 & $\begin{array}{l}\text { F: 5'-tggaagacagtgggagacatc-3' } \\
\text { R: 5'-gcgggtgatggagtaaagtaac-3' }\end{array}$ & 62 & 764 & PCR-RFLP \\
\hline & PM12 & $\begin{array}{l}\text { F: 5'-tgcacacgaaaacacaaact-3' } \\
\text { R: 5'-tccctatgtttgtettttacc-3' }\end{array}$ & 61 & 654 & \\
\hline & PM13 & $\begin{array}{l}\text { F: 5'-atggctcctagtcagatttgttt-3' } \\
\text { R: 5'-acctcagcagaaacgtcagtg-3' }\end{array}$ & 60 & 740 & \\
\hline & PM14 & $\begin{array}{l}\text { F: 5'-caacacaattcaactcaggtataa-3' } \\
\text { R: 5'-caagatgttagctgtactgagaa-3' }\end{array}$ & 55 & 1005 & \\
\hline
\end{tabular}

$\mathrm{F}$ and $\mathrm{R}$ indicate forward and reverse primer; $\mathrm{AT}=$ annealing temperature; $\mathrm{RT}=$ reverse transcription; $\mathrm{PCR}=$ polymerase chain reaction.

\section{Genomic structure and variation analysis of the pig $R F R P$ gene}

The obtained cDNA in this study was used for BLAST search (http://mgc.ucsc.edu/cgibin/hgBlat) to reveal the genomic organization of pig RFRP gene. According to the predicted genome organization, primers $\mathrm{P} 5$ to $\mathrm{p} 10$ were used to amplify the genomic sequence to identify potential polymorphisms by using 25 DNA templates, and then directly sequenced by BGIShenzhen (Guangdong, China). The sequence blast was performed using Seqman program of DNASTAR software package (www.dnastar.com/), and only those variations that presented at least twice were regarded as SNPs.

\section{SNP genotyping by PCR-RFLP}

From the obtained SNPs, appropriate enzymes were selected using mapdraw program of DNASTAR software to genotype by PCR-RFLP; the following enzymes were used: PstI, StyI, SmaI, BsrI, HhaI, and HinfI for SNP of g.45859333T $>$ C, g.45859759C >T, g.45859814G $>$ T, g.45859938A $>$ G, g.45861084T $>$ G, and g.45862152T $>$ A, respectively ( 7 and P11-P14). The digestion mixture contained $8 \mu \mathrm{L}$ PCR products, $1 \mu \mathrm{L} 10 \mathrm{X}$ digestion buffer, and 3.0 U enzyme. Digestion was performed at $37^{\circ} \mathrm{C}$ overnight. The digested PCR products 
were electrophoresed on $2.5 \%$ agarose gel and visualized using a TFM-40 UV Transilluminator.

\section{Real-Time PCR analysis of RFRP mRNA expression in pig tissues}

The $20-\mu \mathrm{L}$ qPCR mixture contained $1 \mu \mathrm{L}$ cDNA template, $0.2 \mu \mathrm{L} 10 \mu \mathrm{m}$ primers, and $10 \mu \mathrm{L}$ EvaGreen suppermix. qPCR was performed at $95^{\circ} \mathrm{C}$ for $3 \mathrm{~min}$, followed by 40 cycles of $30 \mathrm{~s}$ at $95^{\circ} \mathrm{C}, 30 \mathrm{~s}$ at $61^{\circ} \mathrm{C}$, and $40 \mathrm{~s}$ at $72^{\circ} \mathrm{C}$ by using BIO-RAD CFX96 (Bio-Rad, USA). A specific PCR band was obtained by performing melting curve analyses. In addition, qPCR products were verified by sequencing on BGI-Shenzhen (Guangdong, China).

The experiments were repeated in triplicate. Quantitative values were obtained from the threshold PCR cycle number $(\mathrm{Ct})$, at which the increase in signal was associated with an exponential growth for PCR products to be detected. The relative mRNA levels in each sample were normalized by $\beta$-actin. The relative expression levels of pig RFRP gene was indicated by $2^{-\Delta \Delta \mathrm{Ct}}$, for which $\Delta \Delta \mathrm{Ct}=\Delta \mathrm{Ct}_{\text {sample }}-\Delta \mathrm{Ct}_{\text {female cerebrum }}\left(\Delta \mathrm{Ct}=\mathrm{Ct}_{\text {target gene }}-\mathrm{Ct}_{\text {B-actin }}\right)$.

\section{Bioinformatic analysis}

The protein and CDS data of RFRP in various species were downloaded from NCBI database according to the BLAST result of Human RFRP. They were human (protein ID of NP_071433, CDS ID of AB040290.1), chimpanzee (XP_001160762.1; XM_001160762.1), marmoset (XP_002751507.1; XM_002751461.1), Rhesus monkey (BAE17051.1; AB193141.1), cattle (NP_776593.1; NM_174168.1), sheep (NP_001120740.1; NM_001127268.1), house mouse (AĀK94202.2; AB040289.1), Norway rat (AAK94203.2; AF330059.2), and chicken (AAR14159.1, AY442186.1). Alignment of RFRP was performed using the MEGA 4.1 software (www.megasoftware.net/), and identity percentage was deduced using the DNASTAR software (www.dnastar.com/). Furthermore, a series of online services were used to predict physical properties (http://www.expasy.org/tools/protparam.html), signal peptide (http://www.cbs.dtu.dk/services/SignalP/), and transmembrane domain (http://www.cbs.dtu.dk/services/TMHMM/).

\section{Marker trait association analyses}

Association analyses of marker traits were performed using the SAS 8.0 GLM procedure (Liu et al., 2011; Zhang et al., 2012), and the genetic effects were analyzed using the following mixed model:

$$
\mathrm{Y}=\mu+\mathrm{G}+\mathrm{P}_{\mathrm{i}}+\mathrm{S}_{\mathrm{j}}+\mathrm{e}
$$

where $Y$ is an observation on the trait, $\mu$ is the overall population mean, $G$ is the fixed effect of genotype, $P_{\mathrm{i}}$ is the fixed effect of parity ( $\mathrm{i}=1,2,3,4,5$, and 6$), S_{\mathrm{j}}$ is fixed effect of breed ( $\mathrm{j}=$ 1 for Yorkshire and 2 for Landrace), and $e$ is the residual random error. Multiple comparisons were analyzed with least squares means. The values were considered to be significant at $\mathrm{P} \leq$ 0.05 and presented as least squares means $\pm \mathrm{SE}$.

\section{Codon usage bias analysis}

The codon usage bias was analyzed using the online service (http://www.bioinformat- 
ics.org/sms2), and relative synonymous codon usage (RSCU) was calculated using the following mixed model (Comeron and Aguadé, 1998; Carbone et al., 2003):

$$
\mathrm{R}_{\mathrm{ij}}=\mathrm{k}\left(\mathrm{N}_{\mathrm{j}} / \mathrm{N}_{\mathrm{aa}}\right)
$$

where $R_{i j}$ refers to the number of times codon $\mathrm{j}$ was used for the CDS sequence; $\mathrm{i}, k$ refer to the quantity of synonymous codons; $N_{j}$ is the amount of codon $j$ in the CDS sequence, and $N_{a a}$ is the total frequency of synonymous codons in the CDS sequence.

\section{RESULTS}

\section{The pig RFRP cDNA sequence and online prediction of protein function}

The obtained pig RFRP cDNA was 645 bp in length containing 564 bp ORF, 37 bp 5'UTR and 44 bp 3'UTR and it encoded a protein of 188 amino acids (AA; NCBI accession No. JN857935; Figure 1). The cDNA sequence of pig RFRP gene showed identities of 81, 68.8 , and $76.1 \%$ with those of human, mouse, and rat, respectively. Their corresponding protein homology was 69.1, 54.7, and 56.1\%, respectively. Prediction indicated that RFRP peptide was an instable and hydrophobic protein, of which the isoelectric point (IP) was 10.34. Moreover, the pig RFRP contained a signal peptide located at LLT-SN and a transmembrane domain located at MEIISSKRFVLWTLAASSLLTSNIFCTD.

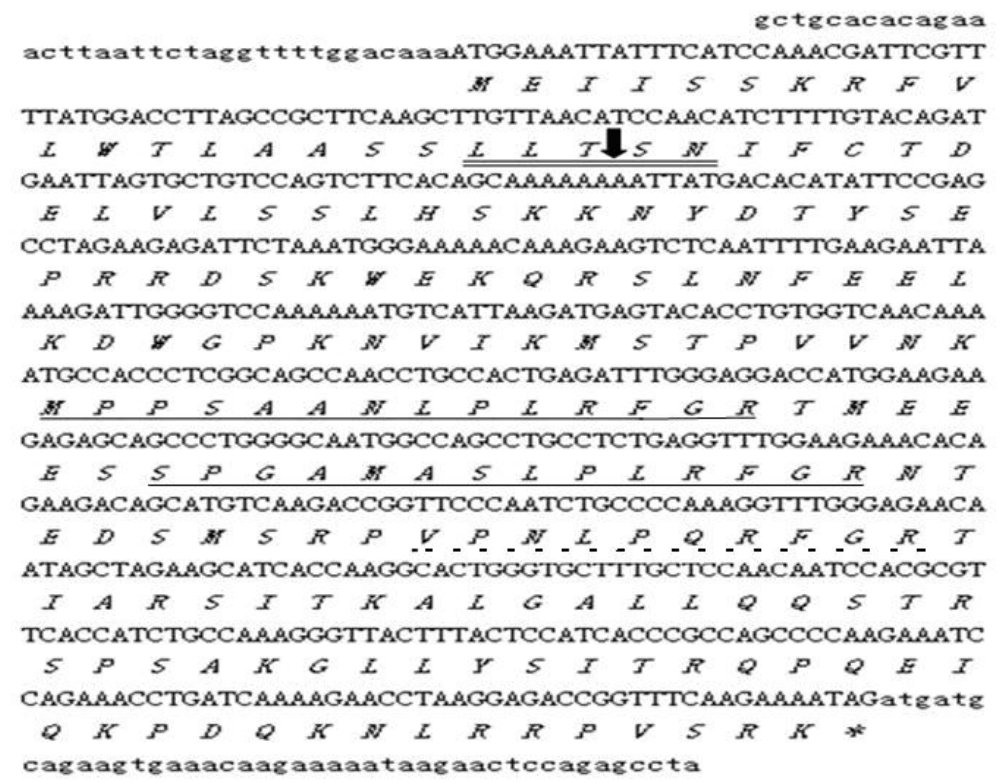

Figure 1. cDNA and deduced amino acid sequences of pig RFRP gene. Capital and italic letters showed amino acids for each codon upside, while asterisk refers to stop codon. Double uderline showed the predicted cleavage sequence of signal peptide, and inverted arrowhead showed cleavage site. The single underline referred to peptide sequence of RFRP-1, which has LPLRF sequence. The broken line referred to peptide sequence of RFRP-3 with sequence of LPQRF. No matter RFRP-1 or RFRP-3, both amino acids ended with GR (Glycine, Arginine). 


\section{Homology of RFRP in 10 species}

Blast search showed that pig RFRP exhibited higher homology with cattle (84\%) and sheep (94.3\%; Figure S1). The CDS homology was higher than the protein homology among all analyzed species. Moreover, the "RFGR" and similar "RFGR" motifs of "RFamide" structure could be found in the 10 species (Figure S1). A total of 31 codons showed bias of usage on the basis of relative synonymous codon usage (RSAU) $>1$.

\section{Genomic characterization of pig RFRP gene}

The pig RFRP gene is located at $45857868-45862257 \mathrm{nt}$ of pig chromosome 18 (reverse strand) spanning $4517 \mathrm{bp}$, and it contains 3 exons and 2 introns (Figure 2). The nucleotide sizes of exon 1-3 are 175, 404, and $196 \mathrm{bp}$, respectively, and they are 1585 and 2157 bp for introns 1 and 2 each. The boundary nucleotides of the 2 introns followed the putative "GT-AG" rule.

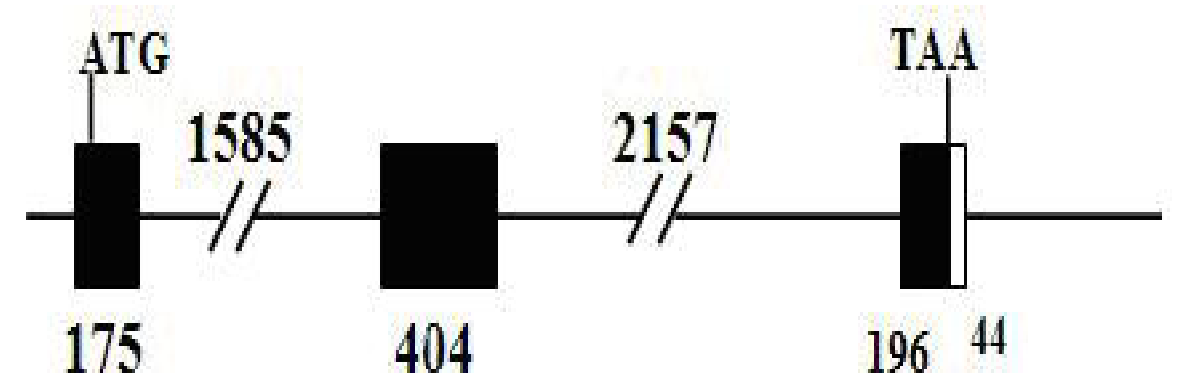

Figure 2. Genomic organization of pig RFRP gene. ATG is initiation codon, and TAA is stop codon. The black boxes indicated exons with nucleotide size showed below. Double bars indicated introns with nucleotide size shown upside. The white box indicated the 3'UTR obtained in this study.

\section{RFRP mRNA expression in various tissues}

qPCR showed that pig RFRP gene was expressed in most tissues in both females and males (Figure 3; Table S1). In females, the highest mRNA was found in the large intestine $(2.30 \pm 0.275)$, and then in the uterus (1.36 \pm 0.246$)$, liver $(1.14 \pm 0.224)$, lymph (1.09 $\pm 0.0791)$, stomach $(1.05 \pm 0.168)$, cerebrum $(1.00 \pm 0.0898)$, subcutaneous fat $\left(8.56 \times 10^{-1}\right.$ $\pm 0.212)$, cerebellum $\left(8.30 \times 10^{-1} \pm 0.271\right)$, lung $\left(7.60 \times 10^{-1} \pm 0.0502\right)$, kidney $\left(6.73 \times 10^{-1}\right.$ $\pm 0.250)$, ovary $\left(5.06 \times 10^{-1} \pm 0.0906\right)$, small intestine $\left(3.87 \times 10^{-1} \pm 0.239\right)$, abdominal fat

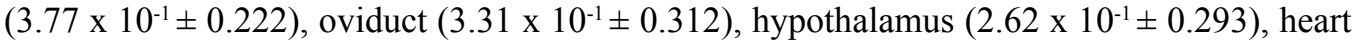
$\left(2.44 \times 10^{-1} \pm 0.515\right)$, back muscle $\left(1.82 \times 10^{-1} \pm 0.0332\right)$, pituitary $\left(1.39 \times 10^{-1} \pm 0.276\right)$, back leg muscle $\left(1.34 \times 10^{-1} \pm 0.245\right)$. The lowest mRNA was found in the spleen $\left(7.60 \times 10^{-2} \pm\right.$ $0.541)$ and foreleg muscle $\left(2.84 \times 10^{-2} \pm 0.674\right)$. In males, the highest can be detected in the digestive system of stomach, and then it was found in the liver, cerebrum, hypothalamus, and cerebellum. Interestingly, the reproductive system of testis also had higher mRNA levels than in other tissues. 


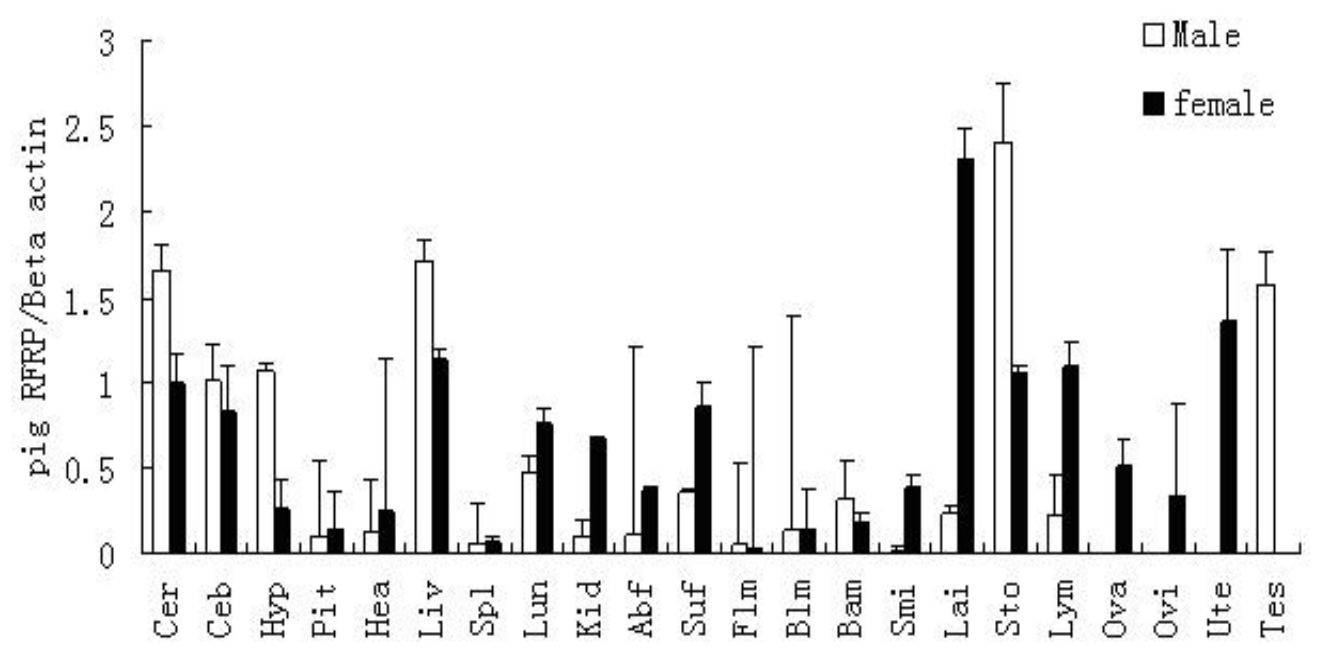

Figure 3. mRNA levels of pig RFRP gene in different tissues of male and female Yorkshire. Cer = cerebrum; Ceb= cerebellum; Hyp = hypothalamus; Pit = pituitary; Hea = heart; Liv = liver; $\mathrm{Spl}=$ spleen; Lun = lung; Kid = kidney; $\mathrm{Abf}=$ abdominal fat; Suf = subcutaneous fat of back; Flm = forth leg muscle; Blm = back leg muscle; Bam $=$ Back muscle; Smi = small intestine; $\mathrm{Lai}=$ large intestine; Sto = stomach; Lym = lymph; Ova = ovary; Ovi = oviduct; Ute $=$ uterus, and Tes $=$ testis.

\section{SNPs of pig RFRP gene}

A total of 25 SNPs and 2 indels were identified in the $4157 \mathrm{bp}$ region of pig RFRP gene (Table 2). The mean SNP density was calculated every 154 bp per SNP. Among 9 SNPs in exons, 6 are missense mutations, i.e., g.45859759C $>\mathrm{T}$, g.45859795C $>\mathrm{T} / \mathrm{A}$, g.45859796A $>$ G, g.45859822C $>$ T, g.45859938A $>$ G, and g.45862152T $>$ A. Three others (g.45859754G $>$ A, g.45859814G $>$ T, and g.45859922C $>$ T) are synonymous mutations. Moreover, the SNP of g. $45859795 \mathrm{C}>\mathrm{T} / \mathrm{A}$ was a multiple allele variation. Since 20 of these SNPs were located at the sites of specific restriction enzymes, they could be genotyped by PCR-RFLP.

\begin{tabular}{l}
\multicolumn{7}{c}{ Table 2. Single nucleotide polymorphisms (SNPs) of pig RFRP gene identified in this study. } \\
\hline \begin{tabular}{clllllll}
\hline No. & Site & Region & SNP & No. & Site & Region & SNP \\
\hline 1 & 45859333 & Intron 1 & $\mathrm{T}>\mathrm{C}$ & 15 & 45861084 & Intron 2 & $\mathrm{T}>\mathrm{G}$ \\
2 & 45859349 & Intron 1 & $\mathrm{C}>\mathrm{T}$ & 16 & 45861412 & Intron 2 & $\mathrm{C}>\mathrm{T}$ \\
3 & 45859516 & Intron 1 & $\mathrm{T}>\mathrm{C}$ & 17 & 45861489 & Intron 2 & $\mathrm{T}>\mathrm{C}$ \\
4 & $45859573-45859577$ & Intron 1 & $\mathrm{CTTAA}>\mathrm{Del}$ & 18 & 45861588 & Intron 2 & $\mathrm{T}>\mathrm{C}$ \\
5 & 45859608 & Intron 1 & $\mathrm{T}>\mathrm{C}$ & 19 & $45861656-45861657$ & Intron 2 & Ins $>\mathrm{TT}$ \\
6 & 45859626 & Intron 1 & $\mathrm{C}>\mathrm{T}$ & 20 & 45861717 & Intron 2 & $\mathrm{T}>\mathrm{C}$ \\
7 & 45859754 & Exon 2 & $\mathrm{G}>\mathrm{A}$ & 21 & 45861823 & Intron 2 & $\mathrm{A}>\mathrm{G}$ \\
8 & 45859759 & Exon 2 & $\mathrm{C}>\mathrm{T}$ & 22 & 45861850 & Intron 2 & $\mathrm{T}>\mathrm{A}$ \\
9 & 45859795 & Exon 2 & $\mathrm{C}>\mathrm{T} / \mathrm{A}$ & 23 & 45861893 & Intron 2 & $\mathrm{T}>\mathrm{G}$ \\
10 & 45859796 & Exon 2 & $\mathrm{A}>\mathrm{G}$ & 24 & 45862061 & Intron 2 & $\mathrm{C}>\mathrm{T}$ \\
11 & 45859814 & Exon 2 & $\mathrm{G}>\mathrm{T}$ & 25 & 45862120 & Intron 2 & $\mathrm{C}>\mathrm{G}$ \\
12 & 45859822 & Exon 2 & $\mathrm{C}>\mathrm{T}$ & 26 & 45862127 & Intron 2 & $\mathrm{T}>\mathrm{C}$ \\
13 & 45859922 & Exon 2 & $\mathrm{C}>\mathrm{T}$ & 27 & 45862152 & Exon 3 & $\mathrm{T}>\mathrm{A}$ \\
14 & 45859938 & Exon 2 & $\mathrm{A}>\mathrm{G}$ & & & & \\
\hline
\end{tabular}
\end{tabular}

The site of each SNP was determined based on pig genome at chromosome 18, according to November 2009 (SGSC Sscrofa9.2/susScr2) pig BLAT search (http://genome.ucsc.edu/cgi-bin/hgBlat). 


\section{Association of the pig RFRP gene polymorphisms with reproductive traits}

In this study, 6 SNPs were chosen to analyze their associations with reproductive traits. Results showed that only g.45859759C $>$ T was significantly associated with the TBA of second parity $(\mathrm{P}<0.05$; Table 3$)$.

Table 3. Association of 45859759C $>$ T with pig reproduction traits
\begin{tabular}{lllllll}
\hline SNPs & RFLP enzyme & Traits & P value & Least squares mean $(\mathrm{LSM}) \pm$ standard error (SE) \\
\hline $45859759 \mathrm{C}>\mathrm{T}$ & StyI $(E c o 130 \mathrm{I})$ & TBA2 & 0.0403 & $11.74 \pm 0.45(\mathrm{CC} / 35)^{\mathrm{ab}}$ & $11.40 \pm 0.18(\mathrm{TC} / 237)^{\mathrm{a}}$ & $10.55 \pm 0.17(\mathrm{TT} / 238)^{\mathrm{b}}$ \\
\hline
\end{tabular}

TBA2 referred to the total number of second. The bracketed letters and numbers indicate genotype and individuals. Values within a row with no common superscript letters differ significantly $(\mathrm{P}<0.05)$.

\section{DISCUSSION}

In this study, the complete CDS of pig RFRP gene was isolated by RT-PCR and were submitted to the NCBI database with their protein sequence, and its predicted molecular weight was $21.22 \mathrm{kDa}$. The encoded pig RFRP gene shared identities of $81,68.8$, and $76.1 \%$ with its counterparts in human, mouse, and rat, respectively. Nevertheless, interestingly, the homology of pig RFRP protein was lower than that of CDS, and the result was consistent with those found in other species. By using the MSM software, we analyzed a total of 31 codons, of which codon bias was noted in 10 species, and the higher frequency codons were AAA (107), GAA (102), AGA (84), CTG (57), and AAT (56). Like humans and mice, the pig RFRP gene also contained 3 exons and 2 introns, and all introns followed the rule of GT-AG. In addition, the pig RFRP peptide also contained 2 forms of RFRP-1 (MPPSAANLPLRF-NH ${ }_{2}$ ) and RFRP-3 (VPNLPQRF-NH ${ }_{2}$ ), just as those in humans (Ubuka et al., 2009).

The expression of $R F R P$ gene in various species was very different. In mouse, the $R F R P$ gene can be detected in the hypothalamus, pituitary, eyes, brain, testis (Hinuma et al., 2000), and ovary (Singh et al., 2011). In humans and hamster, the tissues of hypothalamus, and pituitary showed a litter higher mRNA level. The high expression of pig RFRP gene in reproductive and other tissues indicated its functions in these systems. The pig RFRP gene was found to abundantly expressed in the nervous system (cerebellum, cerebrum, hypothalamus, and pituitary), digestion system (large intestine, stomach), reproduction system (ovary, oviduct, uterus, and testis), and other tissues (liver, lymph, lung, and kidney). In female pigs, the highest expression was found in the large intestine, and then in the uterus. In male pigs, the highest expression was found in the stomach, which also is a digestive organ, and then was in the liver. The lowest mRNA level was detected in the small intestine, while in female pig was forth leg muscle. Regardless of whether male or female pigs were used, both reproductive systems showed a little higher mRNA expression. Accordingly, whether this was related to the feeding actions and reproduction remained unclear in mammals, whereas, in the study of Galvin et al. (1993), the larger uterine capacity was found to be useful for the maintenance of a higher number fetuses.

Until recently, the polymorphisms of pig $R F R P$ gene were unclear, except for 3 variations reported in human (Schulz et al., 2002). In this study, 25 SNPs and 2 indels were identified, of which one-third were located in exons, and most of them predominantly changed between $\mathrm{A} \leftrightarrow \mathrm{G}$ and $\mathrm{C} \leftrightarrow \mathrm{T}$ (Pettersson et al., 2009). Six SNPs (g.45859333T $>C$, g.45859759C $>$ T, 
g.45859814G $>$ T, g.45859938A $>$ G, g.45861084T $>$ G, g.45862152T $>$ A) were selected to analyze the association with some pig reproductive traits in Yorkshire (334) and Landrace (187) populations. Results showed that only g.45859759C $>\mathrm{T}$ was significantly associated with TBA2 $(\mathrm{P}<0.05)$. A recent study also revealed the effects of RFRP-3 on the female pig reproductive axis in vitro ( $\mathrm{Li}$ et al., 2013). It was therefore suggested that pig RFRP gene are a crucial candidate gene for reproduction traits in pigs.

\section{ACKNOWLEDGMENTS}

Research supported by the National Major Special Projects on New Varieties Cultivation for Transgenic Organisms (\#2008ZX08006-005 and \#2009ZX08009-145B) and the Important Projects in Key Fields in Guangdong and Hongkong, 2008 (\#2008A02).

\section{Supplementary material}

\section{REFERENCES}

Bechtold DA and Luckman SM (2007). The role of RFamide peptides in feeding. J. Endocrinol. 192: 3-15.

Carbone A, Zinovyev A and Képès F (2003). Codon adaptation index as a measure of dominating codon bias. Bioinformatics 19: 2005-2015.

Clarke IJ, Qi Y, Puspita S, I and Smith JT (2009). Evidence that RF-amide related peptides are inhibitors of reproduction in mammals. Front Neuroendocrinol. 30: 371-378.

Comeron JM and Aguadé M (1998). An evaluation of measures of synonymous codon usage bias. J. Mol. Evol. 47: 268274.

Ebling FJ and Luckman SM (2008). RFAmide-related peptide: another sexy peptide? Endocrinology 149: 899-901.

Galvin JM, Wilmut I, Day BN, Ritchie M, et al. (1993). Reproductive performance in relation to uterine and embryonic traits during early gestation in Meishan, large white and crossbred sows. J. Reprod. Fertil. 98: 377-384.

Hinuma S, Shintani Y, Fukusumi S, Iijima N, et al. (2000). New neuropeptides containing carboxy-terminal RFamide and their receptor in mammals. Nat. Cell Biol. 2: 703-708.

Kriegsfeld LJ (2006). Driving reproduction: RFamide peptides behind the wheel. Horm. Behav. 50: 655-666.

Kriegsfeld LJ, Gibson EM, Williams WP, III, Zhao S, et al. (2010). The roles of RFamide-related peptide-3 in mammalian reproductive function and behaviour. J. Neuroendocrinol. 22: 692-700.

Legagneux K, Bernard-Franchi G, Poncet F, La RA, et al. (2009). Distribution and genesis of the RFRP-producing neurons in the rat brain: comparison with melanin-concentrating hormone- and hypocretin-containing neurons. Neuropeptides 43: 13-19.

Li X, Su J, Fang R, Zheng L, et al. (2013). The effects of RFRP-3, the mammalian ortholog of GnIH, on the female pig reproductive axis in vitro. Mol. Cell. Endocrinol. 372: 65-72.

Liu LQ, Li FE, Deng CY and Xiong YZ (2011). Molecular cloning, tissue expression and association of porcine NR4A1 gene with reproductive traits. Mol. Biol. Rep. 38: 103-114.

Nichols R, Demers LA, Larsen BM, Robinson D, et al. (2010). Human RFamide-related peptide-1 diminishes cellular and integrated cardiac contractile performance. Peptides 31: 2067-2074.

Pettersson FH, Anderson CA, Clarke GM, Barrett JC, et al. (2009). Marker selection for genetic case-control association studies. Nat. Protoc. 4: 743-752.

Price DA and Greenberg MJ (1977). Structure of a molluscan cardioexcitatory neuropeptide. Science 197: 670-671.

Revel FG, Saboureau M, Pevet P, Simonneaux V, et al. (2008). RFamide-related peptide gene is a melatonin-driven photoperiodic gene. Endocrinology 149: 902-912.

Sambrook J, Fritsch EF and Maniatis R (1989). Molecular Cloning: A Laboratory Manual. 2nd edition. Cold Spring Harbor Laboratory Press, Cold Spring Harbor, New York, 147-194.

Schulz HL, Stoehr H, White K, van Driel MA, et al. (2002). Genomic structure and assessment of the retinally expressed RFamide-related peptide gene in dominant cystoid macular dystrophy. Mol. Vis. 8: 67-71.

Seminara SB, Messager S, Chatzidaki EE, Thresher RR, et al. (2003). The GPR54 gene as a regulator of puberty. N. Engl. 
J. Med. 349: 1614-1627.

Singh P, Krishna A, Sridaran R and Tsutsui K (2011). Immunohistochemical localization of GnRH and RFamide-related peptide-3 in the ovaries of mice during the estrous cycle. J. Mol. Histol. 42: 371-381.

Ubuka T, Morgan K, Pawson AJ, Osugi T, et al. (2009). Identification of human GnIH homologs, RFRP-1 and RFRP-3, and the cognate receptor, GPR147 in the human hypothalamic pituitary axis. PLoS One 4: e8400.

Yoshida H, Habata Y, Hosoya M, Kawamata Y, et al. (2003). Molecular properties of endogenous RFamide-related peptide-3 and its interaction with receptors. Biochim. Biophys. Acta 1593: 151-157.

Zhang W, Fang M, Li Y, Nie Q, et al. (2012). Identification of TDRP1 gene and its association with pig reproduction traits. DNA Cell Biol. 31: 371-377. 